\title{
Determination Sun Protecting Factor (SPF) Of Krokot Herbs Extract (Portulacaoleracea L.)
}

\section{Penentuan Nilai Sun Protecting Factor (SPF) Herba Krokot (Portulacaoleracea L.)}

\author{
Widya Astuty Lolo ${ }^{1 *}$, Sri Sudewi ${ }^{1}$, Hosea Jaya Edy ${ }^{1}$ \\ ${ }^{1}$ Program Study Farmasi, Universitas Sam Ratulangi, Manado - SULUT \\ *email korespondensi 1 : widyaastutylolo@yahoo.com
}

\begin{abstract}
Purslane is a plant that thrives in open areas and has a fairly high water content. Hereditary purslane plant has been used for skin protection from the sun. The aim of this study is to determine the value of Sun Protecting Factor (SPF) of ethanol extracts, soluble and insoluble fractions of ethyl acetate from purslane herb.Extraction using maceration method by ethanol 90\%. Fractionation process is the partition obtained soluble and insoluble fractions of ethyl acetate. Absorbance values read using UV-VIS spectrophotometry at a wavelength of $290-320 \mathrm{~nm}$. SPF value is obtained for the ethanol extract 19.495, 20.829 for the soluble fraction of ethyl acetate and 30.055 for an insoluble fraction of ethyl acetate.
\end{abstract}

Key word: Purslane Herbs, SPF, spectrophotometry

\begin{abstract}
Abstrak: Krokot merupakan tanaman liar yang tumbuh subur pada daerah terbuka dan memiliki kandungan air yang cukup tinggi. Secara turun-temurun tanaman Krokot telah digunakan untuk pelindung kulit dari sengatan sinar matahari. Tujuan penelitian kali ini adalah menentukan nilai Sun Protecting Factor (SPF) dari ektrak etanol dan fraksi larut serta tidak larut etil asetat dari herba Krokot. Ekstrasi mengunakan metode maserasi dengan pelarut etanol $90 \%$. Proses fraksinasi secara partisi diperoleh fraksi larut dan tidak larut etil asetat. Pembacaan nilai absorbansi mengunakan spektrofotometri UV-VIS pada panjang gelombang 290-320 nm. Nilai SPF yang didapat adalah 19,495 untuk ekstrak etanol, 20,829 untuk fraksi larut etil asetat dan 30,055 untuk fraksi tidak laruT etil asetat.
\end{abstract}

Key word: Herba krokot, SPF, spektrofotometri 


\section{Pendahuluan}

Efek berbahaya dari radiasi matahari disebabkan terutama oleh ultraviolet (UV) wilayah spektrum elektromagnetik, yang dapat dibagi menjadi tiga wilayah: UV-A(320400nm); UV-B(290-320nm) dan UV-C(200-290nm). Radiasi UV-C dapat disaring atmosfer sebelum mencapai bumi sehingga tidak membahayakan. Radiasi UV-B tidak sepenuhnya disaring oleh lapisan ozon sehingga dapat menyebabkan kerusakan kulit karena terbakar sinar matahari. Radiasi UV-A dapat mencapai lapisan yang lebih dalam dari epidermis dan dermis dan dapat menyebabkan terjadinya penuaan dini pada kulit. Radiasi ultraviolet yang berlebih merupakan salah satu faktor penyebab kanker kulit (Walters et al., 1997).

Tanaman Krokot (Portulaca oleracea L.) merupakan tanaman liar yang tumbuh di tanah lembab dan basah. Secara empiris Krokot merupakan salah satu tanaman yang digunakan untuk menyembuhkan diare, bisul dan infeksi kulit(Dalimartha, 2009; Suwito, 2010). Krokot juga digunakan pada kulit untuk melindungi dari radiasi sinar matahari (Hariana, 2005). Pemanfaatan krokot sebagai antibiotik dan pelindung kulit karena kandungan kimiawinya diantaranya flavonoid, fenolik, tanin mana fenolik dan air yang tinggi (Nisakorn et al, 2013).

Nilai SPF diukur sebagai kemampuan atau efektivitas suatu bahan sebagai tabir surya. Nilai SPF didefinisikan sebagai rasio dari sedikitnya jumlah energi ultraviolet yang dibutuhkan untuk menghasilkan eritema minimal atau terbakar pada kulit yang dilindungi tabir surya dengan jumlah energi yang dibutuhkan untuk menghasilkan eritema yang sama pada kulit tanpa tabir surya.Dengan demikian nilai SPF menunjukkan kemampuan produk tabir surya untuk mengurangi eritema yang diakibatkan karena radiasi sinar UV(Suryanto, 2012).

Ekstrak tanaman Krokot memiliki potensi sebagai agen photoprotective karena komposisi kimia yang dimiliki dan memiliki sifat antioksidan yang baik bagi kesehatan kulit. Oleh karena itu, perlu dilakukan penelitian untuk mencari sumber alternatif agen photoprotective yang efektif dan lebih aman untuk digunakan dalam produk tabir surya serta dalam persiapan pembuatan sediaan kosmetika.

\section{Bahan dan Metode}

\subsection{Alat dan Bahan}

Reagen yang digunakan dalam penelitian ini didapat dari Sigma-Aldrich (St Louis, USA). Spektrofotometer digunakan UV 1800 spektrofotometer Shimadzu. Tanaman Krokot dikumpulkan dari Manado, Sulawesi Utara, Indonesia. Identifikasi botani dilakukan oleh Departemen Biologi, Fakultas Matematika dan Ilmu Pengetahuan, Universitas Sam Ratulangi, Manado. 


\subsection{Ekstraksi}

Herba Krokot sebanyak 2 kilogram dicuci dengan air mengalir kemudian dikeringkan selama 4 hari di dalam oven suhu $40^{\circ} \mathrm{C}$. Herba kering kemudian diblender hingga menjadi serbuk yang dapat diayak dengan ayakan tepung. Serbuk Krokot direndam dengan etanol 90\% selama 5 hari dalam gelap pada suhu kamar. Pengadukan dilakukan secara konstan setiap 8 jam selama 15 menit. Setelah selesai proses maserasi kemudian filtrat disaring dan didapat ekstrak cair. Ekstrak kental sebanyak 35 gram diperoleh dengan menguapkan pelarut yang terkandung dalam ekstrak cair dengan alat rotary evaporator. Didapatkan ekstrak etanol kental untuk diuji nilai SPF dan dilakukan fraksinasi menggunakan etil asetat

Fraksinasi dilakukan menggunakan pelarut etil asetat yang dilakukan secara partisi terhadap ekstrak kental etanol herba Krokot dengan bobot 10 gram. Hasil dari fraksinasi didapatkan fraksi yang larut etil asetat seberat 4,25 gram dan fraksi tidak larut etil asetat seberat 3,85 gram. Hasil fraksinasi dipisahkan dan siap diuji nilai SPF.

\subsection{Penentuan Nilai SPF}

Nilai SPF dihitung secara in vitro menggunakan metode spektrofotometri sesuai dengan penelitian Wungkana et al (2013). Sampel uji masing-masing yaitu ekstrak kental etanol, fraksi larut dan fraksi tidak larut etil asetat diencerkan menggunakan etanol $95 \%$ $(1 \mathrm{mg} / \mathrm{ml})$. Serapan dari setiap sampel uji ditentukan pada spektrofotometer UV-Visible pada panjang gelombang 290 sampai 320nm.Penbacaan nilai absorbansi setiap interval 5 dari panjang gelombang $290 \mathrm{~nm}$ sampai panjang gelombang 320nm.

Untuk menghitung nilai SPF digunakan rumus :

$$
\mathrm{SPF}=\mathrm{CF} \times \sum_{290}^{320} E E(\lambda) \times \mathrm{I}(\lambda) \mathrm{x} \text { absorbansi }(\lambda)
$$

Keterangan :

$$
\begin{array}{ll}
\mathrm{CF} & =\text { Faktor Korelasi }(10) \\
\mathrm{EE} & =\text { Efisiensi Eriterma } \\
\mathrm{I} & =\text { Spektrum Simulasi Sinar Surya } \\
\mathrm{Abs} & =\text { nilai serapan yang terbaca }
\end{array}
$$

\section{Hasil dan Pembahasan}

Metode ekstraksi adalah maserasi yang dilakukan pada suhu kamar sehingga dapat mencegah reaksi pembentukan radikal bebas. Suhu tinggi dapat menginisiasi pembentukan reaksi radikal bebas. Pelarut yang digunakan adalah etanol 90\% (polar) sehingga senyawa yang terkandung dalam sampel adalah senyawa polar. Fraksinasi digunakan dengan metode partisi menggunakan pelarut etil asetat yang bersifat semi polar. Hasil dari fraksinasi adalah fraksi larut ethil asetat dan fraksi tidak larut etil asetat. Ekstrak etanol herba krokot dan kedua hasil fraksi inilah yang akan dihitung nilai SPF. 
Nilai SPF merupakan kemampuan suatu bahan sebagai tabir surya. Tujuan dari tabir surya adalah mencegah kulit terbakar dan kerusakan kulit lainnya yang disebabkan oleh radiasi sinar UV. Dalam penelitian ini ekstrak dan fraksi herbal Krokot dievaluasi dengan spektrofotometri UV. Hasil pembacaan serapan atau absorbansi dari setiap sampelterdapat pada tabel 1. Nilai absorbansi dari sampel ujidibacapada panjang gelombang 290-320nm.

Tabel 1. Perhitungan nilai absorbansi dari sampel uji

\begin{tabular}{|c|c|c|c|c|c|c|c|}
\hline \multirow{2}{*}{$\begin{array}{c}\text { Panjang } \\
\text { Gelombang }\end{array}$} & \multirow{2}{*}{ EE } & \multicolumn{2}{|c|}{ Ekstrak Etanol } & \multicolumn{2}{c|}{$\begin{array}{c}\text { Fraksi Tidak } \\
\text { Larut Etil Asetat }\end{array}$} & \multicolumn{2}{c|}{$\begin{array}{c}\text { Fraksi Larut Etil } \\
\text { Asetat }\end{array}$} \\
\cline { 3 - 8 } & & I & EE x I & I & EE x I & I & EE x I \\
\hline 290 & $\mathbf{0 , 0 1 5}$ & $\mathbf{4 , 0 0 0}$ & $\mathbf{0 , 0 6 0}$ & $\mathbf{4 , 0 0 0}$ & $\mathbf{0 , 0 6 0}$ & $\mathbf{4 , 0 0 0}$ & $\mathbf{0 , 0 6 0}$ \\
\hline 295 & $\mathbf{0 , 0 8 2}$ & $\mathbf{4 , 0 0 0}$ & $\mathbf{0 , 3 2 7}$ & $\mathbf{4 , 0 0 0}$ & $\mathbf{0 , 3 2 7}$ & $\mathbf{4 , 0 0 0}$ & $\mathbf{0 , 3 2 7}$ \\
\hline 300 & $\mathbf{0 , 2 8 7}$ & $\mathbf{2 , 8 8 5}$ & $\mathbf{0 , 8 2 9}$ & $\mathbf{4 , 0 0 0}$ & $\mathbf{1 , 1 5 0}$ & $\mathbf{3 , 4 6 6}$ & $\mathbf{0 , 9 9 6}$ \\
\hline 305 & $\mathbf{0 , 3 2 8}$ & $\mathbf{1 , 4 6 5}$ & $\mathbf{0 , 4 8 0}$ & $\mathbf{2 , 8 1 6}$ & $\mathbf{0 , 9 2 3}$ & $\mathbf{1 , 5 1 7}$ & $\mathbf{0 , 4 9 7}$ \\
\hline 310 & $\mathbf{0 , 1 8 6}$ & $\mathbf{0 , 9 4 8}$ & $\mathbf{0 , 1 7 7}$ & $\mathbf{2 , 0 0 0}$ & $\mathbf{0 , 3 7 3}$ & $\mathbf{0 , 7 8 7}$ & $\mathbf{0 , 1 4 7}$ \\
\hline 315 & $\mathbf{0 , 0 8 4}$ & $\mathbf{0 , 7 6 9}$ & $\mathbf{0 , 0 6 4}$ & $\mathbf{1 , 7 2 4}$ & $\mathbf{0 , 1 4 4}$ & $\mathbf{0 , 5 6 5}$ & $\mathbf{0 , 0 4 7}$ \\
\hline 320 & $\mathbf{0 , 0 1 8}$ & $\mathbf{0 , 6 8 3}$ & $\mathbf{0 , 0 1 2}$ & $\mathbf{1 , 6 0 4}$ & $\mathbf{0 , 0 2 9}$ & $\mathbf{0 , 4 8 2}$ & $\mathbf{0 , 0 0 9}$ \\
\hline
\end{tabular}

Keterangan : EE = Efisiensi Eritema (ketetapan); I = Spektrum Simulasi Sinar Surya

Nilai SPF dari setiap ekstrak didapat dari hasil dari total penjumlahan Efisiensi Eriterma dikalikan Spektrum Simulasi Sinar Surya (EE x I) yang dikalikan Faktor Korelasi (CF) yaitu 10. Total penjumlahan EE x I pada ekstrak etanoladalah 1,9495425 dan dikalikan 10 maka nilai SPF yang didapat adalah 19,495. Nilai SPF untuk fraksi tidak larut etil asetat adalah 3,0054556 dikalikan 10 maka didapat hasil 30,055. Nilai SPF dari fraksi larut etil asetat diperoleh dari 2,0828643 dikalikan 10 maka didapat nilai 20,829. Gambaran nilai SPF dari setiap sampel uji dapat dilihat pada gambar 1. Berdasarkan Wilkinson and Moore (1982) ketiga sampel uji ini termasuk kategori proteksi tabir surya ultra atau terbaik dan terbesar.

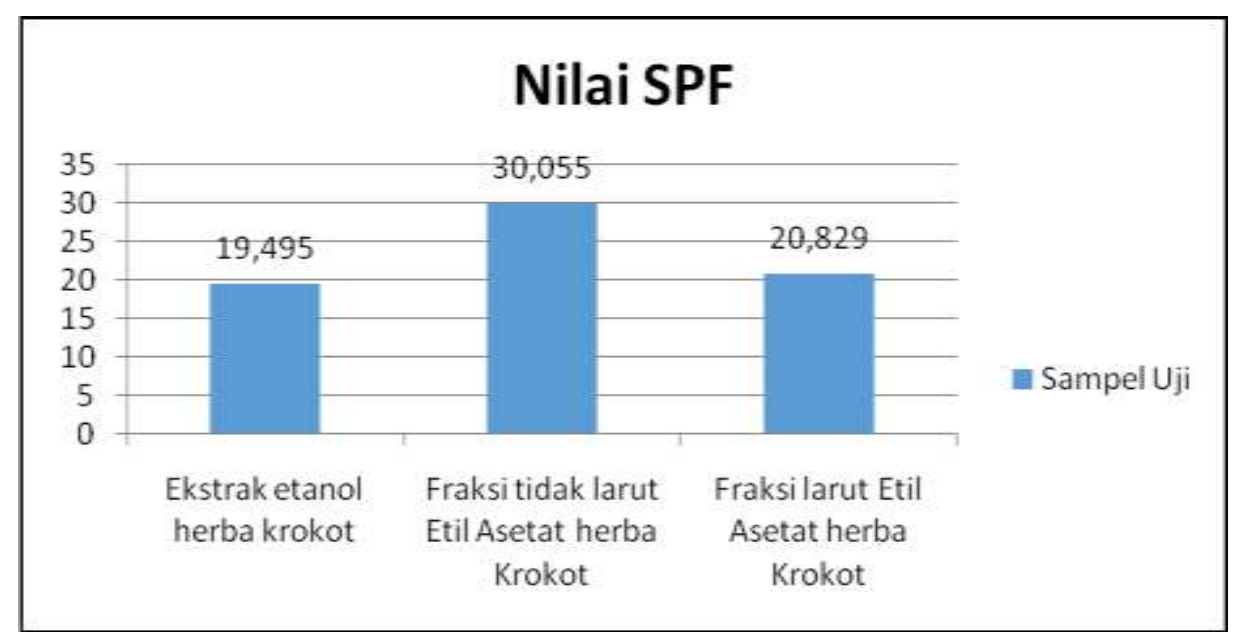

Gambar 1. Nilai SPF setiap sampel uji 
Kandungan kimia yang tinggi pada herba Krokot diantaranya flavonoid dan fenolik maka ekstrak dan fraksi tanaman ini memiliki potensi fotoproteksi karena kemampuannya menyerap sinar UV. Flavonoid dan fenolik juga memiliki kemampuan sebagai antioksidan dan juga bersifat sebagai antiinflamasi dan imunomodulator. Peran flavonoid dan fenolik sendiri dalam tanaman adalah melindungi tanaman dari radiasi UV matahari (Nisakorn et al, 2013 dan Shantanu et al, 2014).

\section{Kesimpulan}

Nilai SPF dari ekstrak etanol adalah19,495. Fraksi larut etil asetat memiliki nilai SPF 20,829. Fraksi tidak larut etil asetat memiliki nilai SPF tertinggi yaitu 30,055. Ketiga jenis bahan ini berdasarkan nilai SPF memiliki proteksi tabir surya dalam kategori ultra.

\section{Ucapan Terimakasih}

Terimakasih kepada prodi farmasi Universitas Sam Ratulangi atas fasilitas laboratorium selama penelitian berlangsung.

\section{Conflict of Interest}

Tidak terdapat potensi konflik

\section{Daftar Pustaka}

Dalimartha, S. 2009. Atlas Tumbuhan Obat Indonesia Jilid 6. Pustaka Bunda,Jakarta.

Hariana, A. 2005. Tumbuhan Obat dan Khasiatnya Seri 2. Pesebar Swadaya, Jakarta.

Nisakorn, S., Ampa, J. 2013. Photoprotection of Natural Flavonoids, Journal of Applied Pharmaceutical Science, 3, (09) :129-141.

Shantanu, K., Kapil, K., Khanderao, J. 2014. Formulation and InVitro Evaluation for Sun Protection Factor of Cosmos Sulphurus Flowers (Asteraceae) Extract Sunscreen Cream, International Journal Pharmacy. 4 (3) : 174-181.

Suwito, W. 2010. Bakteri Yang Sering Mencemari Susu: Deteksi, Patogenesis, Epidemiologi, Dan Cara Pengendaliannya. Jurnal Litbang Pertanian. 29, (3).

Suryanto, E. 2012. Fitokimia Antioksidan. Putra Media Nusantara, Surabaya .

Walters, C., Keeney, A., Wigal, C.T., Johnston, C.R., and Cornelius, R.D., 1997, Spectroscopy Analysis and Modelling of Sunscreens, J. Chem. Educ., 74, (1) : 99 101.

Wilkinson, J, B., \& Moore, R, J., 1982, Harry's Cosmeticology 7ed. New York. Chemical Publishing Company, 3 : 231-232, 240-241, 248

Wungkana, I., Suryanto, E., Momuat, L., 2013, Aktivitas Antioksidan Dan Tabir Surya Fraksi Fenolik Dari Limbah Tongkol Jagung (Zea Mays L.), Pharmacon., 2, (4) : 149-155. 